\title{
SATISFACTION EVALUATION MODEL OF HIGH-LEVEL ATHLETES MANAGEMENT SYSTEM IN UNIVERSITIES OF SICHUAN PROVINCE OF CHINA
}

\author{
Tang Yudong ${ }^{1,2, *}$, Mohd Salleh Aman' ${ }^{1}$ Lim Boon Hooi ${ }^{1}$, Siswantoyo ${ }^{3}$ \\ ${ }^{1}$ University of Malaya, Malaysia \\ ${ }^{2}$ Neijiang Normal University, China \\ ${ }^{3}$ Yogyakarta State University, Indonesia \\ *e-mail: tangyudong321@qq.com
}

\begin{abstract}
The purpose of this study was to develop a questionnaire to measure satisfaction levels of Sichuan Province high-level athletes with their management systems using field investigation and mathematical statistics. Through the process of sorting and analyzing existing literature and in combination with the results of expert interviews, an 'initial questionnaire' consisting of 58 items and 6 dimensions was formed. As first steps, content validity and face validity of the questionnaire were tested. Then, SPSS 24 and Smart PLS 3 were used to carry out exploratory factor analysis (EFA) and confirmatory factor analysis (CFA) respectively. After the unqualified items were deleted, a formal questionnaire comprising 49 items and 6 dimensions was ultimately formed. Reliability and validity tests demonstrated that the questionnaire had good internal consistency reliability and structural validity. By analyzing the structural model, it is found that the model has good prediction accuracy and prediction relevance, and the model fit is also good. Therefore, the evaluation model constructed in this study could be used as a tool for surveying satisfaction levels of Sichuan Province high-level athletes with their university management systems.
\end{abstract}

Keywords: satisfaction, high-level athletes, management system, universities, China

\section{MODEL EVALUASI KEPUASAN SISTEM MANAJEMEN ATLET TINGKAT TINGGI DI UNIVERSITAS PROVINSI SICHUAN CINA}

\begin{abstract}
Abstrak: Tujuan dari penelitian ini adalah untuk mengembangkan kuesioner untuk mengukur tingkat kepuasan atlet tingkat tinggi Provinsi Sichuan dengan sistem manajemen dengan menggunakan investigasi lapangan dan statistik matematika. Melalui proses pengurutan dan analisis literatur yang ada dan dikombinasi dengan hasil wawancara ahli, 'kuesioner awal' yang terdiri dari 58 item dan 6 dimensi yang disusun. Sebagai langkah pertama, validitas isi dan validitas muka dari kuesioner diuji. Kemudian, SPSS 24 dan Smart PLS 3 digunakan untuk melakukan analisis faktor eksplorasi (EFA) dan analisis faktor konfirmatori (CFA) masing-masing. Setelah item yang tidak memenuhi syarat dihapus, kuesioner formal yang terdiri dari 49 item dan 6 dimensi akhirnya terbentuk. Uji reliabilitas dan validitas menunjukkan bahwa kuesioner memiliki reliabilitas konsistensi internal yang baik dan validitas struktural. Dengan menganalisis model struktural, ditemukan bahwa model memiliki akurasi prediksi yang baik dan relevansi prediksi, dan model fit juga baik. Oleh karena itu, model evaluasi yang dibangun dalam penelitian ini dapat digunakan sebagai alat untuk mensurvei tingkat kepuasan atlet tingkat tinggi Provinsi Sichuan dengan sistem manajemen universitas.
\end{abstract}

\section{Kata Kunci: kepuasan, atlet tingkat tinggi, sistem manajemen, universitas, Cina}

\section{INTRODUCTION}

'High-level athlete' refers to students with sports talent, who are officially admitted to general universities according to China's admission policy for high-level athletes (Zhu, Zhang, \& Hu, 2016). China's Ministry of Education began setting up high-level sports teams (HLSTs) in 1987, starting with 51 pilot schools. By 2019, 287 Chinese universities are qualified to recruit high-level athletes (Education Ministry of China, 2019; Hair, Hult, Ringle, \& Sarstedt, 2014). This seems to indicate that China is very supportive of building HLSTs in universities. However, feedback of their sports 
experience by athletes representing China in the recent World University Games suggests that few athletes have really been adequately trained by their universities. This is far from the original intention of the Chinese Ministry of Education to set up highly talented sports teams in tertiary education, and use third level institutions as important channels for training high-level athletes (Qiu \& Xu, 2013).

Zeng (2001) believes that proper management is a prerequisite for ensuring the establishment and maintenance of training, competing, studying and self-discipline amongst members of high proficiency teams in universities. Much scholarly research has been conducted on managing HLSTs in order to improve the quality of running teams in universities. China's Ministry of Education has set out a series of objectives and specific valuemeasures to ensure university HLST standards. However, the evaluation is conducted under the guidance of the government, and potentially the universities being evaluated may consciously or unconsciously align their value-orientation and goals with the requirements of the government in order to obtain realistic administrative benefits, or to meet the needs or goodwill of the competent authorities, possibly ignoring their own autonomy and the unique values of the their own university HLSTs (Zhang, 2017).

According to Chinese government enrollmentpolicy, high-levelathletesinuniversities are primarily students, and then athletes. Highlevel athletes are recruited to universities and receive higher education in China. According to International Standards Organization (ISO) 9000:2000, standard scientific research, design and development, and training and education are all included in the tertiary education service industry (Hui Liu, 2011). The World Trade Organization (WTO) classifies service trades into 12 categories, of which the fifth is education. Therefore, the management of high-level athletes in universities can be studied based on the theory of customer satisfaction.

According to the available reviewed literature, there appears to be no research related to satisfaction levels of high-level athletes themselves with their own management systems, from their own perspective. Duan, Li, \& Luo (2009) believe that improving the level of sports by improving the satisfaction of high-level athletes is a topic worth studying. Therefore, from the perspective of high-level athletes, this paper compiled a questionnaire to evaluate the satisfaction of high-level athletes in Sichuan province with their university management system, which provides important theoretical basis for improving the management level of high-level athletes in universities.

\section{High-level Athletes Management System}

Management structures of high-level athletes in China are a type of 'vertical management'. The advantage of this is that it can achieve unified leadership and instruction form the top down. However, this type of management structure is simple and is not conducive to mobilizing enthusiasm in university sports associations and in lower levels of management (Wang, 2012).

The internal management agency of college high-level sports teams lies somewhere between independent mode and non-independent mode. Under the leadership of the headmaster in charge of sports, it forms a 'high-level sports team leading group'. This agency is formed by leaders from the Headmaster's Office, Dean's Office, Admissions Office, Finance Office, Sports Department, and other related departments. It is responsible for recruitment, learning, training, and other related matters (Liu, Mu \& Liu, 2011).

Chinese scholars are continuing to try and establish an evaluation system for management of HLSTs. For example, Zhan (2007) established a management evaluation system for Jiangsu Province university HLSTs using analytic hierarchy process (AHP) supported by suggestions from experts. The evaluation system includes 1 second-order construct and 5 first-order constructs (school competitive sports management system, sports team personnel management, sports team training management, sports team logistics management and sports team competition management), and has a total of 26 items. From the perspective of performance assessment, Yu, Liu, \& Shi (2013) used analytic hierarchy process and mathematical statistics to construct a comprehensive evaluation index system for high-level basketball teams. It includes 5 second-order constructs, 18 first-order constructs and 41 indicators. The 5 second-order constructs are: organization and leadership, resource conditions, team management, team 
performance, and school group work. Xing (2017) used the Delphi method, analytic hierarchy process and several other research methods in combination with interpretations and suggestions from some university experts on suitable evaluation indicators, to construct a set of evaluation systems for high-level track and field teams in ordinary universities. They included 7 second-order constructs, 35 firstorder constructs and 68 indicators. An overview of relevant research results shows that research objects are mostly provincial HLSTs or general HLSTs and that the Delphi method and analytic hierarchy process are the main research methods employed to devise and construct evaluation systems for HLSTs.

\section{Customer Satisfaction}

Customer satisfaction is that state of feeling formed, when the perceived effect on a customer of all products provided by an organization (including services, activities and processes), is compared with its expected value (Kotler, 1997). This definition clearly demonstrates that satisfaction level is a function of the difference between perceived effect and expected value, and not only conforms to the psychological explanation of satisfaction, but also provides operational theoretical support for empirical research on customer satisfaction.

In 1965, after studying customer expectations, efforts and satisfaction, Cardozo proposed that customer satisfaction would likely lead to repeat purchase. Fishbein \& Ajzen (1975) suggest that corporate service attitudes also affect customer buying behavior. Van Hemel (1977) pointed out that customer satisfaction depends on the degree to which the customer's expected product benefits are realized.

Oliver (1980) put forward a model of difference between performance and expectation. The model proposes that if performance exceeds customer expectation, it will increase customer satisfaction level and produce positive differences. If performance is lower than expected, it will lead to a decline in customer satisfaction and a negative difference. Kano, Seraku, Takahashi, \& Tsuji (1984) pointed out that a company's product quality is closely related to the degree of customer satisfaction that results, and it is on this basis that the Kano model is proposed.
When Robinson \& Fornell (1986) defined the connection between the state of consumer satisfaction and the process of commodity consumption, it resulted in customer satisfaction measurement evolving from a life concept, into a science concept in consumer psychology. This led to opening up a new era of theoretical research on customer satisfaction systems. Fornell (1989) proposed a model called the Fornell Model, which included econometric methods. This model uses partial differential least squares solution, and the index obtained is known as the customer satisfaction index (CSI).

In 1989, Fornell led a team to build the world's first national customer satisfaction index measurement model, the Swedish Customer Satisfaction Barometer (SCSB). In 1994, the United States officially launched the American Customer Satisfaction Index evaluation model, based on it. In 1995, New Zealand, Canada, Taiwan and other countries began to test customer satisfaction in various industries. From 1998, South Korea, Malaysia, Brazil, Mexico, Australia, and Argentina, amongst others, have formulated and carried out relevant research on customer satisfaction evaluation. In 2000, Europe began to gradually establish a European customer satisfaction index evaluation model. From this point, customer satisfaction became established as a systematic, theoretical science.

\section{METHODS \\ Instrument}

This research adopts the quantitative research method. The development of this highlevel athlete management satisfaction evaluation model's questionnaire comprising 58 items was based on the findings of Liu (2011); Riemer \& Chelladurai (1998); Yu (2014); Zhan (2007); Ye, Zhou, \& Yu (2013). Approval was obtained from the University of Malaya Research Ethics Committee-Non Clinical (UMREC), reference number UM.TNC2/UMREC-248. The initial questionnaire was devised using the Likert 5 rating scale and, in formal study, a Likert 7 rating scale was used.

Four appropriate experts in the field were invited to evaluate the questionnaire content validity. After their initial validation, four items (M5, M11, M28 and M41) were deleted. Consequently, the questionnaire acquired better content validity and subsequently 5 high-level 
athletes were asked to complete it. All the athletes were able to complete the questionnaire successfully, indicating that the questionnaire had good face validity.

\section{Sampling method}

The study employed stratified random sampling method to select samples. As of June 2018, there were 607 high-level athletes from 9 universities in Sichuan Province. According to previous research, the formula of $S=\frac{X^{2} N P(1-p)}{d^{2}(N-1)+X^{2} P(1-P)}($ Krejcie \& Morgan, 1970) was used to calculate sample size. In this formula, $\mathrm{S}$ $=$ required sample size. $X^{2}=$ the table value of chi-square for 1 degree of freedom at the desired confidence level $\left(1.96^{2}=3.841\right) . \mathrm{N}=$ population size. $\mathrm{P}=$ population proportion (assumed to be .50 since this would provide the maximum sample size). $d=$ the degree of accuracy expressed as a proportion (.05).

It was calculated that 235 subjects would be sufficient to represent the whole highlevel athletes' population of Sichuan province. According to Connelly (2008), pilot study sample size needs to be $10 \%$ of the sample that is intended for the full study. Hence, this pilot study needed a sample size of at least 24 subjects. At the conclusion of the data collection, 83 questionnaires were collected in the pilot study, of which, 61 were valid. There were 327 collected in the formal study, and 264 were valid.

\section{Data analysis}

'Statistical Package for Social Sciences' (SPSS 24) was used in the pilot study to carry out exploratory factor analysis (EFA). Reliability and validity of the questionnaire were tested, following which a new formal questionnaire was formed. Then, questionnaires were used to conduct formal research, and to conduct confirmatory factor analysis on the survey data using 'Smart PLS 3'. Then, the path coefficient and effects of the model are analyzed, and the prediction accuracy, prediction relevance and the model fit are tested.

\section{FINDINGS AND DISCUSSION Findings Exploratory factor analysis}

Questionnaire reliability

To confirm consistency and stability of the questionnaire, Split-half coefficient and Cronbach's Alpha coefficient (a reflection of internal consistency) were analyzed by software SPSS version 24.0. If both Cronbach's Alpha and Split-half were higher than .7, this would indicate reliability (Hair et al., 2014; Simangunsong, 2019). As shown in Table 1, both the Cronbach's Alpha and Split half of each dimension are higher than the respective standards of .7 and this indicates that the questionnaire has a high reliability.

Questionnaire validity

Since the questionnaire used in this research lacks a solid theoretical foundation, it must be tested for its structural validity. The questionnaire contains six latent variables and this article conducts an exploratory factor analysis on each of them. Following analysis, $\mathrm{KMO}$ values of all dimensions were found to be greater than .7 and significance was less than .01. According to Kaiser (1974), the sample data of each latent variable can be used for factor analysis. According to $\mathrm{Wu}$ (2010), if cumulative percentage exceeds $60 \%$, it indicates

Table 1. Results of Reliability and Structural Validity Analysis ( $n=61)$

\begin{tabular}{lccccc}
\hline Dimension & Cronbach's Alpha & Split-half & KMO & Sig. & Cumulative \% \\
\hline EXP & .85 & .79 & .72 & .001 & 76.47 \\
PMQ & .97 & .92 & .82 & .001 & 76.64 \\
PMV & .93 & .90 & .80 & .001 & 83.23 \\
SAT & .88 & .84 & .72 & .001 & 80.81 \\
COM & .91 & .89 & .71 & .001 & 85.34 \\
LOY & .93 & .91 & .70 & .001 & 88.39 \\
\hline
\end{tabular}

Note: $\mathrm{EXP}=$ Expectation of high-level athletes; $\mathrm{PMQ}=$ Perceived management quality; $\mathrm{PMV}=$ Perceived management value; $\mathrm{SAT}=$ Satisfaction of high-level athletes; $\mathrm{COM}=$ Complaints of high-level athletes. $\mathrm{LOY}=$ Loyalty of high-level athletes. 
that extracted factors are representative for all variables. The KMO value, significance and cumulative percentages of each dimension are shown in Table 1.

When carrying out exploratory factor analysis, factor loading which falls below .4 should be deleted (Stevens, 1992). In exploratory factor analysis for perceived management quality, because 5 items (M20, M23, M29,
M34, M42) had a loading below .4, they were deleted. Following exploratory factor analysis, it was found that it was only possible to get five second-order constructions, instead of the six that had been anticipated, in the dimension of perceived management quality. The factor loadings of perceived management quality after the 6th exploratory factor analysis is shown in Table 2.

Table 2. Factor Loading Table for Perceived Management Quality ( $\mathrm{n}=61)$

\begin{tabular}{|c|c|c|c|c|c|c|}
\hline \multicolumn{2}{|c|}{ Items } & \multicolumn{5}{|c|}{ Component } \\
\hline Code & Recode & TC & LE & DP & LO & EN \\
\hline M26 & TC8 & .83 & & & & \\
\hline M27 & TC9 & .82 & & & & \\
\hline M25 & $\mathrm{TC} 7$ & .81 & & & & \\
\hline M24 & TC6 & .81 & & & & \\
\hline M19 & TC3 & .76 & & & & \\
\hline M18 & $\mathrm{TC} 2$ & .76 & & & & \\
\hline M22 & TC5 & .74 & & & & \\
\hline M17 & $\mathrm{TC} 1$ & .72 & & & & \\
\hline M21 & $\mathrm{TC} 4$ & .71 & & & & \\
\hline M35 & LE5 & & .88 & & & \\
\hline M32 & LE3 & & .79 & & & \\
\hline M30 & LE1 & & .75 & & & \\
\hline M44 & LE7 & & .74 & & & \\
\hline M45 & LE8 & & .69 & & & \\
\hline M33 & LE4 & & .69 & & & \\
\hline M43 & LE6 & & .69 & & & \\
\hline M31 & LE2 & & .68 & & & \\
\hline M7 & DP3 & & & .79 & & \\
\hline M8 & DP4 & & & .77 & & \\
\hline M10 & DP6 & & & .73 & & \\
\hline M4 & DP1 & & & .71 & & \\
\hline M6 & DP2 & & & .70 & & \\
\hline M9 & DP5 & & & .66 & & \\
\hline M36 & LO1 & & & & .82 & \\
\hline M40 & LO5 & & & & .78 & \\
\hline M37 & LO2 & & & & .73 & \\
\hline M38 & LO3 & & & & .67 & \\
\hline M39 & LO4 & & & & .65 & \\
\hline M15 & EN4 & & & & & .84 \\
\hline M13 & EN2 & & & & & .81 \\
\hline M14 & EN3 & & & & & .70 \\
\hline M16 & EN5 & & & & & .67 \\
\hline M12 & EN1 & & & & & .62 \\
\hline Cur & e \% & 20.84 & 38.52 & 52.30 & 64.76 & 76.64 \\
\hline
\end{tabular}

Note: $\mathrm{DP}=$ Development Planning EN=Enrollment Management TC $=$ Training and Competition Management LE=Learning Management LO=Logistics Management 


\section{Confirmatory factor analysis (Measurement Model Evaluation)}

The purpose of confirmatory factor analysis (measurement model assessment) is to confirm reliability and validity of construct measures, therefore providing evidence of suitability of their inclusion in the path model (Hair et al., 2014).

The traditional criterion for internal consistency reliability is Cronbach's alpha, but Composite Reliability is a differing measure of internal consistency reliability. Cronbach's Alpha range is .731-.975, greater than the .7 standard (Hair et al., 2014). The range of Composite Reliability in the model is .848.977, which is more than .7 (Hair et al., 2014). To confirm convergent validity, researchers take into account the outer loadings of indicators (indicator reliability), as well as average variance extracted (AVE) (Hair et al., 2014). The outer loadings range from .550-.916, as shown in Figure 1. If the outer loadings of some indicators are below .7, they should be deleted (Hair et al., 2014). According to Brataningrum and Saptono (2017), if loading factor values are between .5 to .7 , it is not necessary to remove indicators having AVE values higher than .5. So, this study keeps all the items.

Average Variance Extracted (AVE) is a common measure to establish convergent validity on the construct level (Hair et al., 2014). Should AVE be higher than .5, it is considered that the construct is valid (Setiyowati, Pali, Wiyono, \& Triyono, 2019). As can be seen from Table 3 , the AVE value of each construct is greater than .5, and this indicates that convergence validity of the model is good.

Discriminant validity may be assessed more conservatively using Fornell-Larcker criterion. As shown in Table 3, AVE square root values of each latent variable are higher than coefficients of more latent variables. Therefore, it seems to indicate that the tool has sufficient discriminant validity (Hair et al., 2014).

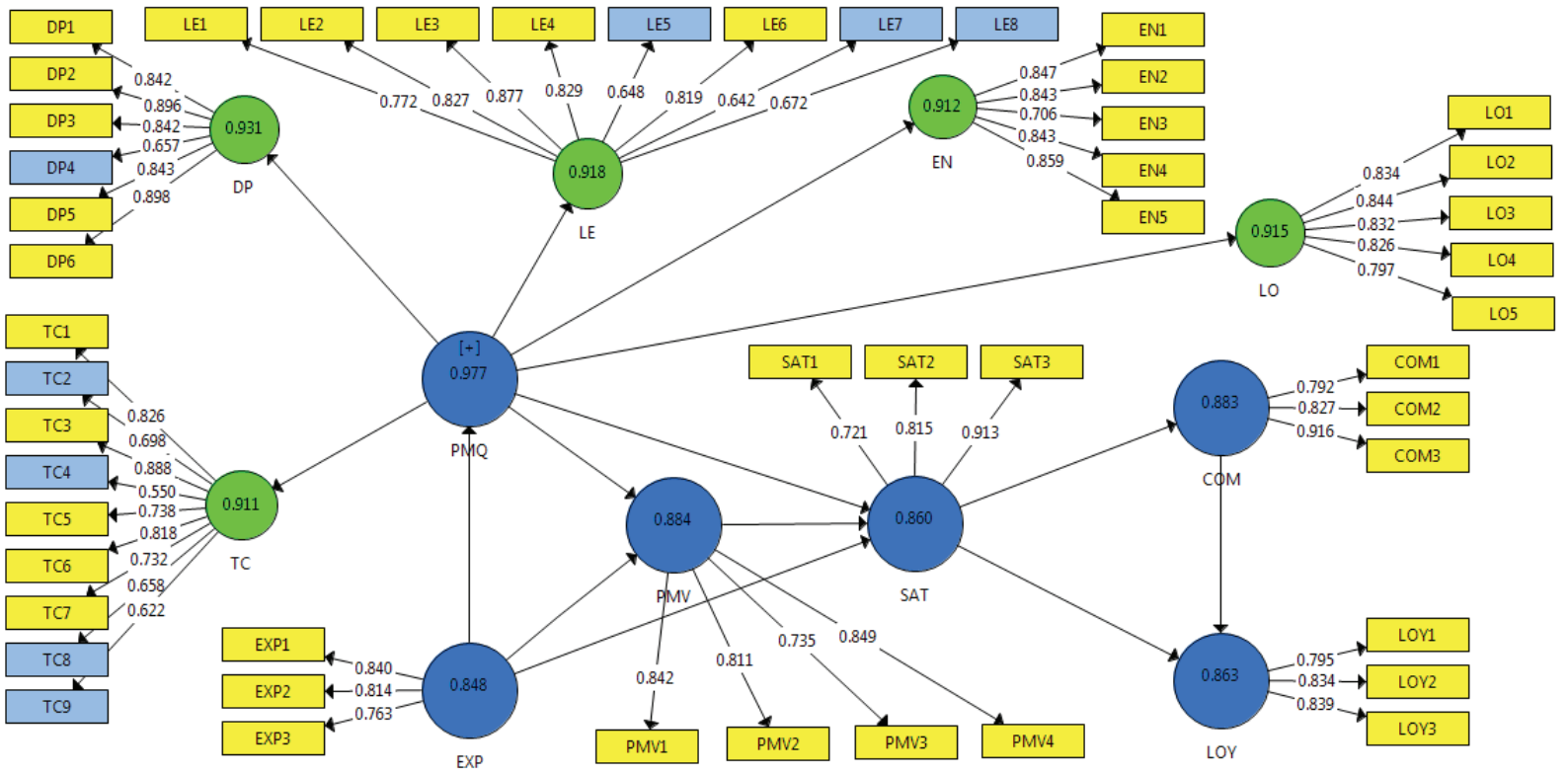

Notes: EXP=Expectation of High-level Athletes, $\mathrm{PMQ}=$ Perceived Management Quality, DP=Development Planning, EN=Enrollment Management, $\mathrm{TC}=$ Training and Competition Management, $\mathrm{LE}=\mathrm{Learning}$ Management, $\mathrm{LO}=$ Logistics Management, $\mathrm{GE}=$ Graduate and Employment Management, PMV=Perceived Management Value, SAT=Satisfaction of High-level Athletes, COM=Complaints of High-level Athletes, LOY=Loyalty of High-level Athletes

Figure 1. Management System Satisfaction Model Outer Loadings 
Table 3. Fit Index of Latent Variables and Fornell-Larcker Criterion $(n=264)$

\begin{tabular}{lccccccccc}
\hline Dimension & Alpha & CR & AVE & COM & EXP & LOY & QUA & VAL & SAT \\
\hline COM & .80 & .88 & .72 & $\mathbf{. 8 5}$ & & & & & \\
EXP & .73 & .85 & .65 & -.32 & $\mathbf{. 8 1}$ & & & & \\
LOY & .76 & .86 & .68 & -.48 & .41 & $\mathbf{. 8 2}$ & & & \\
PMQ & .97 & .98 & .57 & -.32 & .52 & .45 & .75 & & \\
PMV & .83 & .88 & .66 & -.42 & .57 & .55 & .59 & $\mathbf{. 8 1}$ & \\
SAT & .75 & .86 & .67 & -.47 & .46 & .58 & .58 & .64 & $\mathbf{. 8 2}$ \\
\hline
\end{tabular}

Note: $\mathrm{EXP}=$ Expectation of high-level athletes; $\mathrm{PMQ}=$ Perceived management quality; $\mathrm{PMV}=$ Perceived management value; SAT= Satisfaction of high-level athletes; COM=Complaints of high-level athletes.

LOY=Loyalty of high-level athletes.

\section{Structural model Evaluation}

Assessment of multicollinearity

Multiple collinearity refers to the fact that the model estimation is distorted or hard to gauge accurately because of the presence of accurate correlation or high correlation between independent variables in a linear regression model (Yang et al., 2012). When two or more variables predict another variable, the multiple collinearity problem should be checked. According to Hair et al. (2014), tolerance levels below .20 and VIFs greater than 5.0 in the predictors indicated collinearity. According to Table 4 , tolerance is greater than .2 and $\mathrm{VIF}<5$, demonstrating the absence of a multicollinearity issue.

Table 4. VIF and Tolerance Values for Collinearity Evaluation

\begin{tabular}{llll}
\hline $\begin{array}{l}\text { Dependent } \\
\text { Construct }\end{array}$ & $\begin{array}{l}\text { Predictor } \\
\text { Construct }\end{array}$ & Tolerance & VIF \\
\hline PMV & EXP & .726 & 1.377 \\
& PMQ & .726 & 1.377 \\
SAT & EXP & .620 & 1.613 \\
& PMQ & .599 & 1.670 \\
& PMV & .555 & 1.802 \\
LOY & SAT & .779 & 1.285 \\
& COM & .779 & 1.285 \\
\hline
\end{tabular}

Note: EXP=Expectation of high-level athletes; $\mathrm{PMQ}=$ Perceived management quality; $\mathrm{PMV}=$ Perceived management value; $\mathrm{SAT}=$ Satisfaction of high-level athletes; $\mathrm{COM}=$ Complaints of high-level athletes. LOY=Loyalty of high-level athletes.

\section{Path Coefficient}

In this paper, the Bootstrapping function of Smart PLS 3 is used to test significance of path coefficient and whether it is significantly judged according to the size of the $\mathrm{T}$ value. If $|\mathrm{t}|>1.96$, it is significant; on the other hand, if $|\mathrm{t}| \leq 1.96$, it is not significant (Hair et al., 2014). It can be seen from Table 5 that the EXP $\rightarrow$ SAT path coefficient is .065 , the $\mathrm{T}$ value is 1.078 , less than 1.96 , and the $\mathrm{P}$ value is .281 , which is greater than .05 and cannot pass the significance test while the remaining path coefficients pass the significance test. As shown in Figure2.

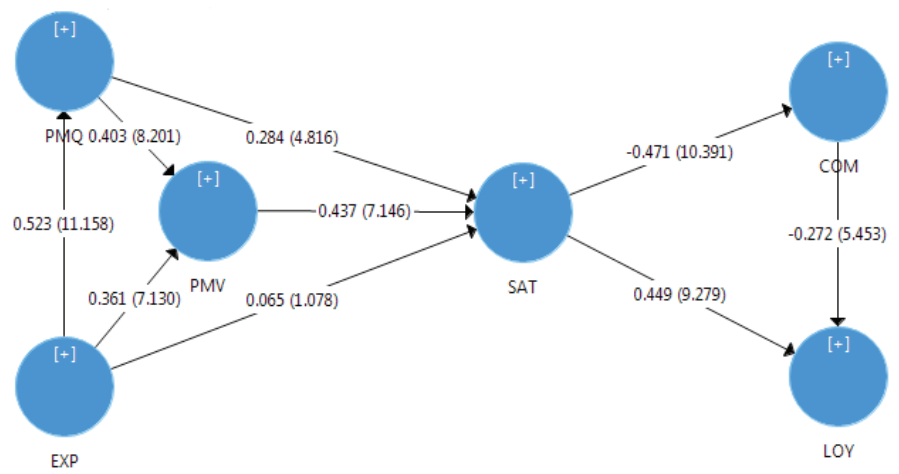

Figure 2. Path Coefficient and Significant Value of The Structural Model $(n=264)$

Note: EXP $=$ Expectation of high-level athletes; $\mathrm{PMQ}=$ Perceived management quality; $\mathrm{PMV}=$ Perceived management value; SAT = Satisfaction of high-level athletes; $\mathrm{COM}=$ Complaints of high-level athletes. LOY $=$ Loyalty of high-level athletes.

Therefore, after removing the path of $\mathrm{EXP} \rightarrow \mathrm{SAT}$, a modified model is obtained. The revised model was re-tested. Results showed that the model's fit index does not change much. However, the path coefficient of PMQ $\rightarrow$ SAT, and $\mathrm{PMV} \rightarrow$ SAT increased. T-test analysis showed that all the values were significant. Hence, this explains that the revised model (as shown in Figure 3 is more suitable. 


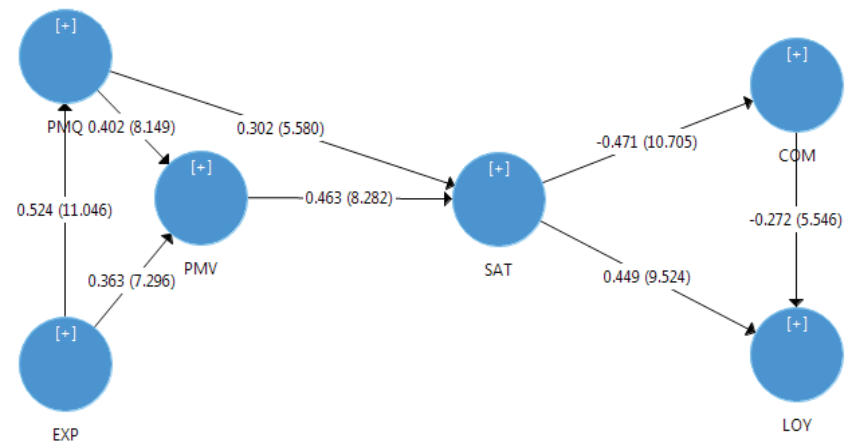

Figure 3. The Revised Satisfaction Model of the Management System of High-Level Athletes

Note: $\mathrm{EXP}=$ Expectation of high-level athletes; $\mathrm{PMQ}=$ Perceived management quality; $\mathrm{PMV}=$ Perceived management value; $\mathrm{SAT}=$ Satisfaction of high-level athletes; $\mathrm{COM}=$ Complaints of high-level athletes. $\mathrm{LOY}=$ Loyalty of high-level athletes.

Path coefficient is inclusive of direct path coefficient and indirect path coefficient, and represents direct and indirect effects, respectively. The sum of direct and indirect effect is total effect. The effect of variables of the modified model is shown in Table 5.

Table 5. Effect of the Revised Model

\begin{tabular}{lccc}
\hline Path & $\begin{array}{c}\text { Direct } \\
\text { effect }\end{array}$ & $\begin{array}{c}\text { Indirect } \\
\text { effect }\end{array}$ & $\begin{array}{c}\text { Total } \\
\text { effect }\end{array}$ \\
\hline $\mathrm{EXP} \rightarrow \mathrm{PMQ}$ & .52 & .00 & .52 \\
$\mathrm{EXP} \rightarrow \mathrm{PMV}$ & .36 & .21 & .57 \\
$\mathrm{EXP} \rightarrow \mathrm{SAT}$ & .00 & .42 & .42 \\
$\mathrm{PMQ} \rightarrow \mathrm{PMV}$ & .40 & .00 & .40 \\
$\mathrm{PMQ} \rightarrow \mathrm{SAT}$ & .30 & .19 & .49 \\
$\mathrm{PMV} \rightarrow \mathrm{SAT}$ & .46 & .00 & .46 \\
$\mathrm{SAT} \rightarrow \mathrm{COM}$ & -.47 & .00 & -.47 \\
$\mathrm{SAT} \rightarrow \mathrm{LOY}$ & .45 & .13 & .58 \\
$\mathrm{COM} \rightarrow \mathrm{LOY}$ & -.27 & .00 & -.27 \\
\hline
\end{tabular}

Note: EXP=Expectation of high-level athletes; $\mathrm{PMQ}=$ Perceived management quality; $\mathrm{PMV}=$ Perceived management value; SAT $=$ Satisfaction of high-level athletes; $\mathrm{COM}=$ Complaints of high-level athletes. LOY=Loyalty of high-level athletes.

Coefficient of Determination $\left(\mathrm{R}^{2}\right)$

The coefficient of determination $\left(\mathrm{R}^{2}\right)$ value is a standard based on which a structural model is compared. It stands for the cumulative effect of the total independent variables on any dependent variables. According to Cohen (1988), .26 is considered as substantial, .13 moderate, and .02 weak. Hair et al. (2014) stated that $\mathrm{R}^{2}$ values of .20 are considered high in disciplines such as consumer behavior, in success driver studies (e.g., in studies that aim at explaining customer satisfaction or loyalty). The $\mathrm{R}^{2}$ of the model is shown in Table 6 . We can see that Perceived Management Quality, Perceived management Value, Satisfaction and loyalty exhibited substantial predictive accuracy, while Complaints and exhibited a moderate predictive accuracy.

\section{Predictive Relevance $\left(\mathrm{Q}^{2}\right)$}

Predictive relevance is found by application of Stone-Geisser's Q ${ }^{2}$ value (Sparks, 2014). Emerging $\mathrm{Q}^{2}$ values $>0$ show that exogenous constructs predict relevance for the endogenous construct being examined (Hair et al., 2014). The $\mathrm{Q}^{2}$ value of the model is shown in Table 6 . All the value of predictive relevance is greater than zero, it indicates that the model is highly predictive.

Table 6. $\mathbf{R}^{2}$ Values and $Q^{2}$ Values of the Model

\begin{tabular}{lcc}
\hline Construct & $\mathbf{R}^{\mathbf{2}}$ & $\mathbf{Q}^{\mathbf{2}}$ \\
\hline EXP & -- & -- \\
COM & .222 & .147 \\
LOY & .390 & .248 \\
PMQ & .274 & .144 \\
PMV & .446 & .274 \\
SAT & .472 & .299 \\
\hline
\end{tabular}

Note: EXP=Expectation of high-level athletes; $\mathrm{PMQ}=$ Perceived management quality; PMV= Perceived management value; $\mathrm{SAT}=$ Satisfaction of high-level athletes; $\mathrm{COM}=$ Complaints of high-level athletes. LOY=Loyalty of high-level athletes.

Model fit

Goodness of Fit (GoF) was proposed by Tenenhaus, Vinzi, Chatelin, \& Lauro (2005) as a diagnostic tool to assess the model fit for PLS-SEM. The GoF is measured by using the geometric mean value of the average communality score (AVE values) and the average $\mathrm{R}^{2}$ values (for endogenous constructs) and is calculated using following equation, $\mathrm{GoF}=$ $\sqrt{\text { average }(\mathrm{AVE}) * \text { average }\left(\mathrm{R}^{\wedge} 2\right)}$

(Tenenhaus et al., 2005). When GoF is greater 
than .36, the model fits well; when GoF is about .25 , the model fits moderately; when GoF is less than .10, the model fits poorly (Wetzels, Odekerken-Schröder, \& Van Oppen, 2009). For the model used in this study, a GoF value of .49 was calculated, indicating a good model fit. But the research of Henseler, Ringle, and Sarstedt (2012) shows that the GoF does not represent a goodness-of-fit criterion for PLS-SEM. Hair et al. (2014) advice that researchers should not use GoF as a measure. Henseler et al. (2014) introduce the Standardized Root Mean Square Residual (SRMR) as a goodness of fit measure for PLS-SEM that can be used to avoid model misspecification. A value of less than .08 is considered a good fit ("Model Fit," 2014). In this research, the SRMR value of this model is .063, less than .08. So, the model fit is also good from the SRMR index.

\section{Discussion}

Through combing the existing literature, it is found that Chinese scholars have done more research on the evaluation system of highlevel sports teams in colleges and universities. From the existing literature, we can see that the management of high-level athletes is an important indicator to evaluate the construction of high-level sports teams, and the different dimensions of high-level athlete's management had been basically determined. Although there is no research on the satisfaction with highlevel athletes' management system, the current researches also provide a strong theoretical basis for this article. For example, Zhou, Zhang, Wei, \& Li (2013) used Delphi method and analytic hierarchy process to construct an evaluation index system for high-level tennis teams in colleges and universities from three aspects: team direction, team management and team performance. The management of sports teams includes four aspects: organization and leadership, conditions and guarantee, coach management and athlete management. Athlete management consists of enrollment management, student status management, cultural learning management, political and ideological management, daily life management, reward and punishment mechanism, training and competition management. Xing (2017) also used Delphi method and analytic hierarchy process to construct the evaluation index system of high-level track and field teams in colleges and universities from seven aspects: team direction, organization and leadership, coach management, sports team management, condition guarantee, performance results and social benefits. Among them, the management of the sports team includes seven aspects: the management of athletes' enrollment, the management of athletes' status as students, the management of athletes' ideological and moral character, the management of athletes' training, the mechanism of athletes' punishment and award, the situation of athletes' further studies and graduation, and the relationship between coaches and athletes.

The existing research is basically from the perspective of experts or managers, through expert interviews, Delphi method, analytic hierarchy process, etc., to screen indicators, and there is no empirical research, therefore, the research results are unconvincing. The purpose of the existing research is to evaluate the quality of team building in colleges and universities, so as to evaluate whether colleges and universities have the qualification of team building but can't give suggestions for improving management. This paper, from the perspective of high-level athletes, screens the indicators for evaluating the management of high-level athletes. From six aspects of development and planning, enrollment management, learning management, training competition management, logistics management, and graduate and employment management, a high-level athlete management system has been established. By means of analysis, it was discovered that combining graduate employment management and learning management made the evaluation index system more reasonable. Therefore, after deleting a few items and merging both graduate employment management and learning management, a relatively comprehensive evaluation system for high-level athlete's management was formed. In addition, referring to the ACSI model, the satisfaction index model of the high-level athlete management system is constructed and verified. Therefore, the satisfaction index system of the management system of high-level athletes in colleges and universities constructed in this paper is more reasonable and scientific, and the content is more targeted.

This study found that although there is no direct or significant influence between 
expectations of high-level athletes (EXP) and satisfaction of high-level athletes (SAT), EXP indirectly and positively affect SAT through two mediator variables: perceived management quality (PMQ) and perceived management value (PMV). This is consistent with the study by Dan, Wang, \& Liu (2018) and Sun, Yang, \& Jiang (2016), who found that there is no direct effect between student expectations and student satisfaction, but that student expectation has indirect effect on student satisfaction through other mediator variables. In some studies, it is believed that higher expectations will lead to lower quality perception (Xu, Cui, \& Ji, 2017). However, in this study, it was found that there was a significant positive relationship between expectations of high-level athletes (EXP) and perceived management quality (PMQ), indicating that EXP have a positive impact on PMQ. Expectations of high-level athletes (EXP) also has a significant positive impact on perceived management value (PMV). Research by Peng, Li, \& Chen (2016) supports this view in finding that customer expectation had a significant positive impact on quality perception and value perception.

Current research finds that there is a significant relationship between perceived management quality (PMQ) and perceived management value (PMV). Other studies have yielded similar results. For example, GarcíaFernández et al. (2018) found a direct positive correlation between perceived quality and perceived value of low-cost fitness centers. In addition, this study found that PMQ not only positively affects PMV, but also positively affects satisfaction of high-level athletes (SAT), and perceived management value (PMV) positively affects satisfaction of high-level athletes (SAT). In the study of Ramseook-Munhurrun, Seebaluck, and Naidoo (2015), perceived value played an important role influencing the level of tourist satisfaction.

It was found that satisfaction of high-level athletes (SAT) negatively affects complaints of high-level athletes (COM). In addition, SAT positively affects loyalty of high-level athletes (LOY). Liu, Chen, Zha, Ling, \& Wang (2018) found through research that customer satisfaction had a negative effect on complaints. Finally, this study also found that complaints of high-level athletes (COM) had a negative effect on the loyalty of high-level athletes (LOY). This is consistent with the researches of Li \& Sun (2008); Shen (2011); Zhou \& Dai (2013), which found that customer complaints is negative significantly correlated with customer loyalty. It appears to show that high-level athletes having higher satisfaction with university management, had less complaints and greater loyalty.

\section{CONCLUSION}

High-level athletes' levels of satisfaction with their management systems arise from their overall feelings and their subjective evaluation of university management systems. Viewed from the satisfaction perspective of high-level athletes, this paper describes the construction of a questionnaire for evaluating their satisfaction with management systems of high-level athletes. Following verification by experts of validity of content, four items were deleted, and it was found that Cronbach's alpha coefficient for the questionnaire lay between .844 and .933 . Over and above this, split-half coefficients of each dimension were from .795-.917, indicating that the questionnaire had good reliability. The cumulative percentage of the model was $76.468 \%-88,387 \%$, further indicating that the questionnaire had good structural validity. Following exploratory factor analysis of dimensions of perceived management quality, it was found that they formed five secondary dimensions. A formal questionnaire with 49 questions was formed, after which an empirical investigation was conducted.

Through analysis of the structural equation model using formal study data, Cronbach' alpha, CR and AVE of the model indicated that measurement model had good internal consistency, convergent validity, and discriminant validity. The path shows the influence of independent variables on dependent variables. Through the analysis of the structural model, it is found that there is no direct effect between the EXP and SAT. $\mathrm{R}^{2}$ shows that the model has higher prediction accuracy. $\mathrm{Q}^{2}$ shows that there is a good predictive relevance between the constructions of the model. In addition, both GoF and SRMR indicate that the model fits well. Therefore, the high-level athlete management system satisfaction evaluation model put forward here may be an effective evaluation tool, which may accurately assess satisfaction levels of highlevel athletes with their management systems, 
thus providing a theoretical basis for universities to improve management of high-level athletes.

\section{REFERENCE}

Brataningrum, N. P., \& Saptono, L. (2017). The influence of the effectiveness of accounting learning process on students' learning achievements. Cakrawala Pendidikan, 36(3), 342-356. doi:10.21831/ cp.v36i3.14139.

Connelly, L. (2008). Pilot studies. Medsurg nursing: Official journal of the Academy of Medical-Surgical Nurses, 17(6), 411412.

Dan, F., Wang, X. X., \& Liu, X. N. (2018). Study on the construction of the satisfaction model of normal college students' educational practice in preschool education based on structural equation. Studies in Preschool Education, (10), 3645. doi:10.13861/j.cnki.sece.2018.10.004.

Duan, F. X., Li, Y., \& Luo, B. (2009). Investigation and strategy study on the satisfaction of high-level athletes in universities of Hubei Province. Journal of Wuhan University of Technology, 31(24), 160-166. doi:10.3963/j.issn.16714431.2009.24.040.

Education Ministry of China. (2019). Notice of the general office of the ministry of education on announcing the technical adjustment results of high-level sports teams in colleges and universities in 2019. https://gaokao.chsi.com.

Fishbein, M., \& Ajzen, I. (1975). Belief, attitude, intention and behavior: An introduction to theory and research. Reading, MA: Addison-Wesley.

Fornell, C. (1989). The blending of theoretical and empirical knowledge in structural equations with unobservables. In Wold, $\mathrm{H}$. (Ed.), Theoretical empiricism: A general rationale for scientific model-building (pp. 153-174). New York, NY: Paragon House Publisher.
García-Fernández, J., Gálvez-Ruíz, P., Fernández-Gavira, J., Vélez-Colón, L., Pitts, B., \& Bernal-García, A. (2018). The effects of service convenience and perceived quality on perceived value, satisfaction and loyalty in low-cost fitness centers. Sport Management Review, 21(3), 250-262. doi:10.1016/j.smr.2017.07.003.

Hair, J. F., Hult, G. T. M., Ringle, C., \& Sarstedt, M. (2014). A primer on partial least squares structural equation modeling (PLS-SEM). Thousand Oaks, CA: Sage.

Henseler, J., Dijkstra, T. K., Sarstedt, M., Ringle, C. M., Diamantopoulos, A., Straub, D. W., . . Calantone, R. J. (2014). Common beliefs and reality about PLS: Comments on Rönkkö and Evermann (2013). Organizational research methods, 17(2), 182-209. doi: $10.1177 / 1094428114526928$.

Henseler, J., Ringle, C. M., \& Sarstedt, M. (2012). Using partial least squares path modeling in advertising research: Basic concepts and recent issues. In Shintaro, O. (Ed.), Handbook of research on international advertising, (pp.252-276). Cheltenham, UK: Edward Elgar Publishing. doi: $10.4337 / 9781848448582.00023$

Kaiser, H. F. (1974). An index of factorial simplicity. Psychometrika, 39(1), 31-36. doi:10.1007/BF02291575.

Kano, N., Seraku, N., Takahashi, F., \& Tsuji, S. (1984). Attractive quality and mustbe quality, hinshitsu. The Journal of the Japanese Society for Quality Control, 14(2), 147-156.

Kotler, P. (1997). Marketing managementanalysis, planning, implementation, and control. New Jersey, NJ: Prentice Hall Inc.

Krejcie, R. V., \& Morgan, D. W. (1970). Determining sample size for research activities. Educational and psychological measurement, 30(3), 607-610. doi:10.1177/001316447003000308. 
Li, H. X., \& Sun, H. Q. (2008). Research on customer satisfaction index model and evaluation index system of exhibition enterprises. Journal of Beijing International Studies University, 30(11), 69-73.

Liu, H. (2011). A research of China higher education student satisfaction based on PLS-SEM model. (Doctoral dissertation, Jiangsu University, Jiangsu, China).

Liu, H., Chen, Y., Zha, Y., Ling, L., \& Wang, D. (2018). The effect of satisfaction on loyalty in consumption and service industry based on meta-analysis and it's algorithm. Wireless Personal Communications, 103(1), 963-982. doi:10.1007/s11277018-5489-8.

Liu, Z. Q., Mu, Y. Q., \& Liu, Z. M. (2011). Research on the management model of high-level sports teams in colleges and universities. China Market, (39), 159-161.

Smart PLS. (2014). Model fit. https://www. smartpls.com/.

Oliver, R. L. (1980). A cognitive model of the antecedents and consequences of satisfaction decisions. Journal of marketing research, 17(4), 460-469. doi:10.2307/3150499.

Peng, D. H., Li, C. L., \& Chen, G. (2016). Spectator satisfaction with professional tennis matches in China in view of Wuhan Open. Journal of Wuhan Institute of Physical Education, 50(6), 77.

Qiu, L. W., \& Xu, C. S. (2013). Restraint factors and their solution of the development of highlevelsportsteaminordinary university. Journal of Guangzhou Sport University, $33(01)$, 115-118. doi:10.13830/j.cnki. cn44-1129/g8.2013.01.027.

Ramseook-Munhurrun, P., Seebaluck, V., \& Naidoo, P. (2015). Examining the structural relationships of destination image, perceived value, tourist satisfaction and loyalty: Case of Mauritius. ProcediaSocial and Behavioral Sciences, 175(2015), 252-259. doi:10.1016/j. sbspro.2015.01.1198.

Riemer, H. A., \& Chelladurai, P. (1998). Development of the athlete satisfaction questionnaire (ASQ). Journal of sport and exercise psychology, 20(2), 127-156. doi:10.1123/jsep.20.2.127.

Robinson, W. T., \& Fornell, C. (1986). Market pioneering and sustainable market share advantages. The PIMSLETTER on Business Strategy, (39).

Setiyowati, A. J., Pali, M., Wiyono, B. B., \& Triyono, T. (2019). Structural model of counseling competence. Cakrawala Pendidikan, 38(1), 45-62. doi:10.21831/ cp.v38i1.21509.

Shen, H. (2011). On the testing model of customers' satisfaction in budget-type hotels based on the framework of ACSI. Tourism Tribune, 26(01), 58-62.

Simangunsong,E.(2019). Factors determining the quality management of higher education: a case study at a business school in indonesia. Cakrawala Pendidikan, 38(2), 215-227. doi:10.21831/cp.v38i2.19685.

Stevens, J. (1992). Applied multivariate statistics for the social sciences $\left(2^{\text {nd }} e d\right)$. Hillsdale, NJ: Lawrence Erlbaum Associates,

Sun, Y. R., Yang, M., \& Jiang, G. (2016). Research on the construction of college teaching practice satisfaction model based on structural equation. Higher Education Exploration, (01), 74-81.

Tenenhaus, M., Vinzi, V. E., Chatelin, Y.-M., \& Lauro, C. (2005). PLS path modeling. Computational Statistics \& Data Analysis, 48(1), 159-205. doi:10.1016/j. csda.2004.03.005.

Van Hemel, O. J. S. (1977). An obstetric data- 
base: human factors, design and reliability. Department of Medical Informatics, Free University, Van der Boechorstraat.

Wang, A. L. (2012). A comparative study of the management on high-level sport team in universities between China and the United States. (Master's thesis, Nanjing Institute of Physical Education and Sports, Nanjing, China).

Wetzels, M., Odekerken-Schröder, G., \& Van Oppen, C. (2009). Using PLS path modeling for assessing hierarchical construct models: Guidelines and empirical illustration. Mis Quarterly, 33(1), 177-195. doi:10.2307/20650284.

Wu, M. L. (2010). Statistical analysis practice of questionnaires: SPSS operation and application. Chongqing, China: Chongqing University Press.

Xing, K. J. (2017). Research on the Construction of evaluation index system for high-level track and field teams in colleges and universities. Contemporary Sports Technology, 7(29), 251-256. doi:10.16655/j.cnki.20952813.2017.29.251

Xu, Z. Y., Cui, X. Z., \& Ji, S. X. (2017). Evaluating migrant workers' satisfaction of public services with a structural equation model. Comparative Economic \& Social Systems, (05), 62-74.

Ye, W., Zhou, Z., \& Yu, Z. F. (2013). A study on the evaluation system of the high-level martial arts teams in regular universities. Journal of Beijing Sport University,, 36(12), 104-114. doi:10.19582/j.cnki.113785/g8.2013.12.020.

Yu, Z. F. (2014). Evaluation index system and method in the construction of high level sports teams in colleges and universities in China. Beijing: Higher education press.

Yu, Z. F., Liu, F., \& Shi, Y. (2013). Research on construction of evaluation index system of high-level basketball teams in universities and colleges in China based on the perspective of performance evaluation. Journal of Xi'an Physical Education University, 30(05), 621$627 . \quad$ doi:10.16063/j.cnki.issn1001747x.2013.05.023.

Zeng, X. S. (2001). A study on management system of Chinese high-level university sports teams. Journal of Wuhan Institute of Physical Education, 3, 99-100. doi:10.15930/j.cnki.wtxb.200.03.038

Zhan, X. Y. (2007). Research on management evaluation system of high level sports team in Jiangsu Province (Master's thesis, Nanjing normal university, JIangsu, Nanjing).

Zhang, C. H. (2017). Factors that affect high performance university sports team construction in China. Journal of Physical Education,, 24(01), 128132. doi:10.16237/j.cnki.cn44-1404/ g8.2017.01.017.

Zhou, J. M., Zhang, Z. H., Wei, X. F., \& Li, X. C. (2013). Research on the evaluation index system of high-level tennis sports teams of university in China. Journal of Beijing Sport University, 36(02), 105-109. doi:10.19582/j.cnki.11-3785/ g8.2013.02.020.

Zhou, L. M., \& Dai, J. Y. (2013). A quantitative study of the factors influencing the degree of satisfaction with service provided by comprehensive family service centre with comprehensive family service centre of $\mathrm{T}$ street in guangzhou as an example. Journal of Guangdong University of Technology, 13(04), 12-19.

Zhu, X. M., Zhang, W. Q., \& Hu, Y. H. (2016). Review on psychological health of Chinese elite college athletes in last twenty years. Bulletin of Sport Science \& Technology, 24(08), 37-40. doi:10.19379/j.cnki. issn.1005-0256.2016. 08. 015. 